\title{
Putative Macrophage-Stimulating Protein MSTP9
}

National Cancer Institute

\section{Source}

National Cancer Institute. Putative Macrophage-Stimulating Protein MSTP9. NCI

Thesaurus. Code C104671.

Putative macrophage-stimulating protein MSTP9 (715 aa, $80 \mathrm{kDa}$ ) is encoded by the human MST 1L gene. This protein is a non-functional member of the peptidase S1 family. 